\title{
READING METAPHOR OF GOD IN THE QUR'AN (AL-NŪR [24]: 36) FROM PAUL RICOEUR'S THEORY OF METAPHOR
}

\author{
Nur Ahmad \\ Vrije Universiteit Amsterdam \\ e-mail: nurahmad@student.vu.nl
}

\begin{abstract}
This paper aims to demonstrate how the adoption of the theory of metaphor by Ricoeur to the "Light Verse" in the Quran. One of the most famous verse in the Quran is "the Light verse." Beside the metaphor of light, the verse includes the metaphors of "the niche", of "the lamp", of "the glass", and others. The metaphor "God is the Light" is the vital feature of the analysis. The next metaphors in the verse are an extension of that metaphor. The "light" metaphor with its principal meaning as "source" will be analyzed using the theory of metaphor as created by Paul Ricoeur in The Rule of Metaphor (1978). The application of this concept will unfold how this metaphor is employed creatively. It makes a parable of the gradation of lights and contains how it is widened to cover a broader aspect of faith, i.e., being the center and open to accept His light. The result of this experiment with metaphors in the Light verse shows fresh analy sis that God illuminates on every creation in all realms.
\end{abstract}

Keywords: metaphor, Paul Ricoeur, the Light Verse, Quranic interpretation.

DOI: http://dx.doi.org/10.20414/ujis.v21i2.279

\section{Introduction}

THIS PAPER focuses on applying the principle of analysis laid down in The Rule of Metaphor (1978) by Paul Ricoeur to the one of the most famous verses of the Quran, namely the "Light Verse" chapter al-Nūr (24) verse 35. This application is hoped to shed light on new perspective on the specific verse as an addition to 
what have been provided by Muslim scholars especially the Quranic commentators for the last fifteen centuries.

The first section of this paper discusses the concept of metaphor, its characteristics and its function to understand religious texts as elaborated by Paul Ricoeur in his The Rule of Metaphor. ${ }^{1}$ The second section of this paper is the main part the paper. It is devoted to the analysis of religious metaphor contained in the "Light Verse" such as light, niche, lamp, glass, East and West, and olive tree under the light of Ricoeur's concept. The last section of this paper is concerned with meta-analysis of the application of metaphorical concept to the general Quranic hermeneutics. Unless otherwise indicated, all translation of the Quran is taken from The Study Quran: A New Translation and Commentary by Hossein Nasr, Caner K. Dagli, Maria Massi Dakake, Joseph E. B. Lumbard. ${ }^{2}$

\section{Metaphor: the power of symbolic language}

While metaphor has been understood in a strict sense as one type of tropes, in its widest sense it is a term that covers all tropes. ${ }^{3}$ In this narrow sense, Paul Ricoeur ${ }^{4}$ identifies metaphor with an act of "giving an unaccustomed name to some other things, which thereby is not being given its proper name." His definition indicates that the main characteristic of a metaphorical language is that it administers some aspects of a word to another alien word. Take the metaphor "God is Light" for an example! In this metaphor, God is given the main aspect of light, that is the source of existence without which human eyes cannot see the corporeal world. We will deeply delve into this notion in the second section of this paper.

${ }^{1}$ Paul Ricoeur, The Rule of Metaphor: Multi-Disciplinary Studies of the Creation

2 Seyyed Hossein Nasr et al., The Study Quran: A New Translation and Commentary, Tra edition. (New York: HarperOne, 2015).

${ }^{3}$ Rene Dirven, "Metaphor as a Basic Means for Extending the Lexicon," in The Ubiquity of Metaphor: Metaphor in Language and Thought, Amsterdam Studies in the Theory and History of Linguistic Science, vol. 29, Amsterdam studies in the theory and history of linguistic science. Series 4, Current issues in linguistic theory, 0304-0763 (Amsterdam [etc.]: Benjamins, 1985), 1.

${ }^{4}$ Ricoeur, The Role. 
In Poetic, ${ }^{5}$ which is the point of departure for Ricoeur, Aristoteles defines "Metaphor is the application of an alien name by transference either from genus to species, or from species to genus, or from species to species, or by analogy." Ricoeur seems to agree with Aristoteles in this regard. However, Ricoeur challenges some aspects considered as characteristics of metaphor by Aristoteles.

For Ricoeur, ${ }^{6}$ the related-meaning of metaphor is with the discourse of the word ("sentence-centered" as he writes) rather than merely with word as Aristoteles believes (word-centered). Ricoeur writes,

"Metaphorical meaning is an effect of the entire statement, but it is focused on one word, which can be called the metaphorical word. This is why we must say that metaphor is a semantic innovation that belongs at once to the predicative order (new pertinence) and the lexical order (para-digmatic deviation). In its first as pect it de pends upon a 'dyna mics' of meaning: under the second, upon a 'statis' or non-dynamic state of a system." 7

He further explains that if a word is understood in isolation, it has only a potential meaning. ${ }^{8}$ Whereas its actual meaning is found in the "complete sentence." As an example, when we say metaphorically, "a lion rushed toward us," the meaning is not automatically clear based on the word "lion" until we have in our mind the speaker's context and his/her way of using it. Inasmuch as there are many aspects of a lion of which we could make metaphor, the meaning could be the bravery way of walking or "be aware, because our land is hunted by a capital company!" This way of understanding marks the notion of "always new situation ... in every act of speech." 9 Based on this rule, therefore, I would always consult to the discourse of a word in the Quran in order to

5 Aristotle and Samuel Henry Butcher, The Poetics of Aristotle (London: Macmillan, 1922), 77, accessed October 9, 2016, http://archive.org/details/poeticsofaristot00arisuoft.

${ }^{6}$ Ricoeur, The Role, 16.

7 Ibid., 156-157.

8 Ibid., 129.

9 W. A. Kort, “Book Review: Review Essay: Paul Ricoeur and the Hermeneutics of Metaphor, the Rule of Metaphor: Multidisciplinary Studies of the Creation of Meaning in Language," Christianity $\mathcal{E}$ Literature 28, no. 2 (1979): 49. 
understand Quranic metaphorical expressions. For instance, metaphor "God is the Light" imposes on me to search for what the Quran says about light throughout its verses.

The second central idea that Ricoeur formulates in his The Rule of Metaphor is that metaphor is in continuous movement between "fixed-meaning" in the language order and the always new situation in every speech. ${ }^{10}$ For Ricoeur, there is no stagnation where a word has its fixed-meaning without any possibility to be "changed" and in case of metaphorical utterance, the metaphor could become - at one point - the lexical meaning itself. In this sense, we could grasp the notion that God is the Real Light that is expressed by al-Ghazālī. ${ }^{11}$ Because al-Ghazālì believes that the Quran is signifying "light" with character of being "visible" and has ability to makes things become visible. Inasmuch as nothing would act as the creator like the Creator Himself, God is the True Light.

As the result of the two abovementioned notions, the last key point Ricoeur illustrates is that metaphor bestows on language the ability to create a new world. ${ }^{12}$ Based on this function, Werner claims that it is through metaphor "for primitive man to gain insight into the natural phenomena around him."13 When the literal word cannot reach the meaning a speaker is eager to convey, metaphor paves the way for it. Therefore, teleological language always takes metaphorical expression as its form.

These three major concepts about metaphor that Ricoeur promotes in his book are the practical guidance for this present study to analyze "the Light Verse." Every metaphorical word is, first, treated as a lexical word with a "literal" meaning. Then, the discourse of the word in the Quran is elaborated to let the Quran speaks for itself. Further investigation is to make a decision on the

${ }^{10}$ Ricoeur, The Role, 110-111; Read also Paul Ricoeur, "Toward Hermeneutic of the Idea of Revelation," Harvard Theological Review 70, no. 1-2 (1977): 1-37.

${ }_{11}$ Abū Ḥāmid Muḥammad ibn Muhạmmad al-Ghazāī and William Henry Temple Gairdner, Ghazzali's Mishkāt Al-Anwwār (The Niche for Lights) (Lahore: Sh. Muhammad Ashraf, 1952), 79.

12 Ricoeur, The Role, 125-126.

${ }^{13}$ Dirven, "Metaphor," 125-126. 
new meaning the Quran attributes to the word by the metaphorical expressions.

\section{Surah al-Nūr's characteristic}

In this section, the verse is analyzed part by part. The first part is the analysis of the metaphor of the Light. The analysis of the niche comes after that, then the glass, the lamp, the olive oil, andthe last metaphor - the tree. The verse of the Quran in question is

"God is the Light of the heavens and the earth. The parable of His Light is a niche, wherein is a lamp. The lamp is in a glass. The glass is as a shining star kindled from a blessed olive tree, neither of the East nor of the West. Its oil would well-nigh shine forth, even if no fire had touched it. Light upon light. God guides unto His Light whomsoever He will, and God sets forth parables for mankind, and God is Knower of all things." 14

Within the traditional Muslim scholars ('ulama'), this verse is considered as one of the most beautiful and famous verses in the Quran from which the sürah takes its name, namely al-Nūr. ${ }^{15}$ Many of them write independent treatises as commentary to the verse. One of the most famous treatises is Mishkāt al-Anwār by al-Ghazālī.

\section{Unveil the Symbol of Light}

"God is the Light of the heavens and the earth" is the main feature of this verse without which to understand the other features is in vain. To understand this metaphor from Ricoeur's concept, the lexical meaning of the word within the tradition in question should be located. In the oldest Arabic lexical dictionary, ${ }^{16}$ the word $n-w-r$ is rendered as exactly what it means by "light" in English. It is the "opposite of dark," "brightness," and "illumination." But, we could discuss here what "brightness" exactly means. When we consider light deeply, one concept arises that characterizes light and makes it different form others. This central characteristic of light is "visibility." Light is visible in itself and makes others visible. Therefore, to name God as light is to ascribe the quality of "the source of existence" to God. In this

\footnotetext{
${ }^{14}$ Nasr et al., The Study.

15 Ibid.

${ }^{16}$ Ibn-'Amr Al-Ḥa līl Ibn Aḥmad and 'Abd al-Ḥāmid Hindā wī, Kitāa al- 'Ain, 4 K - y. Al-Ṭab‘a 1., 4 K - y (Beirut: Dār al-Kutub al-'Ilmyya, 2003), 276.
} 
regard, al-Ghazali ${ }^{17}$ argues for this character so that "light" has its name which is of powerful and rational one. His point of departures is the appearance of the world from the sense of sight. The appearance and non-appearance of something is relative to the sense of sight. Based on this sense, things are one of these categories. First, it is not visible by itself. Second, it is visible by itself but cannot make others visible. Third, it is visible by itself and makes others visible. It is obvious that light is of the last category. Therefore, light needs no color to be the bear witness for its existence. In contrast, any color needs light for their corporeal appearance. This linguistic analysis proposes a conclusion that God needs no creation to be God, but the creation which is everything else is in need of Him to exist. In this sense, al-Ghazāli says that God is the "Real Light", while to name light for others (e.g. sunlight, skylight, light of lamp, etc.) is only metaphorically and expresses no real meaning. ${ }^{18}$

Another way to understand the light here is by looking at different ways of reading the word n-w-r. Șadr al-Dīn Shīrāzī, ${ }^{19}$ based on the report by Imam Ali peace be upon him, proposes that the other way of reading the word $\mathrm{n}-\mathrm{w}-\mathrm{r}$, that is nawwara, meaning to give out light. In this sense, he then attributes the metaphorical expression of light that God is "the Owner of Light" from which the heavens and the earth receive their light which is their existence. By the association of existence to the heavens and earth, which is the way of speaking universe in Arabic, God sets the rule for being. Everything receives their being only if they are associated with God in one way from many ways. This notion is the popular interpretation of the metaphor especially in Sunni Islam. The most crucial function it plays is that it paves the way for the intimate relation in Islam between human and nature which has been severely deteriorated in Western world. ${ }^{20}$ Islamic

17 al-Ghazālī and Gairdner, Ghazzali's Mishkāt, 80.

18 Ibid., 79.

19 Shīrāzī Șadr al-Dīn Muhammad Shīrāzī, Tafsīr al-Qur'ān Al-Karīm, ed. Muhammad Khwaja wi, vol. 4 (Qum: Intisharat-i Bidar, 1987), 349.

${ }^{20}$ For this intimate correlation between spiritual and nature, Nasr has convinced us that it only happens when human has metaphysical background about it. Nature is always the sign of the disclosure of God. Seyyed Hossein Nasr, 
cosmology is that marries the Celestial World and the Terrestrial World. When a Muslim sees the heaven, it is of course something above us, but, not only that, it is also of the symbolic existence where angels reside.

Beside the lexical point of view, Ricoeur's concept inevitably entails us to research on the light discourse in the Quran in order to gain full meaning of this metaphor. In the Holy Quran, the word Nūr "light" is found in 69 places. ${ }^{21}$ In those places, it is of important that the notion of light as an expression of God's guidance, ${ }^{22}$ of one of His beautiful names "asmā' al-husnā" (al-Nūr [24]: 35), and of sacred scriptures which God has sent them down to human ${ }^{23}$ largely dominate the "literal" and "desacralized" meaning as merely "not dark" or "rays" in the physical sense (Yūnus [10]: 5).

As the guidance from God "hidāyah", light is something that shows and guides the people of believe the way to act in accordance with God's commands (al-Baqarah [2]: 257). Inasmuch as that this guidance originates from and shows the straight path to God, every human to whom God gives no light has no light at all. For this Quran says in chapter al-Nūr [24]: 40, "He for whom God has not appointed any light has no light." This spiritual hidāyah would serve her function not only in the life but also in the Day of Judgement since this light transcends the world of meanings. People to whom God appointed light in this life are conscious of the warm and the rays of this light so that in the Hereafter they ask God, "Our Lord, complete our light for us and forgive us. Truly Thou art Powerful over all things" ( al-Tahrīm [66]: 8).

In regard to the guidance contained in sacred scriptures, therefore they are also called Nūr (Light) by the Quran. The guidance of the Quran is the light with which one sees the straight

Man and Nature: The Spiritual Crisis of Modern Man (London (Ruskin House: Mandala Books, 1976).

${ }^{21}$ Jumhuriyyah Miṣr al-'Arabiyyah, Mu'jam Alfāz Al-Qur'ān Al-Karìm, vol. 2 (Majma' al-Lughoh al-'Arabiyyah, 1409), 1134-1135.

${ }^{22}$ In the Cattle [6]: 91, 122; Light [24]: 40; Counsel [42]: 53; Iron [57]: 13, 28; and Noah [71]: 16.

${ }^{23}$ In the Heights [7]: 157 and Mutual Dis possession [64]: 8. 
path to God. The Quran makes a statement for itself in chapter alMā'idah [5]: 15, "There has come unto you, from God, a light and a clear Book." The Quran also acknowledges that Torah contains the light which God pours on its verses (al-Mā'idah [5]:44). In addition, in the verse 46 of the same chapter, the Quran also establishes that the Gospel contains light form God. As the result, it is safe to conclude that the Quranic usage of Nūr is for everything that leads the way to God. It includes the Divine Revelation, the prophets, the intellect ('ilm), and God.

Taking all these concepts of light in the Quran into account and the context of this verse, we come to the conclusion that light in this specific verse bears two sides of light. First, for the universe God as light proposes that He is their source of existence. Second, for people of believe, God as light means that He alone is the Real source of guidance toward Him. Others would become guidance only by association to Him. In other words, "light" is "the source of existence" without which the existence of perceptible world by eyes cannot be grasped. In the same framework, God is the Creator of creation without which no realm would exist. God is also the Ultimate light in the heart of believers. Without His light, no prophets would be sent down, no guidance would be given, and no intellect ('ilm) would be taught, and - as a result - no one would enter the Kingdom of Heaven using the Jehovah witnesses' term.

\section{Unveil the Symbol of Niche}

The parable of His Light is a niche, wherein is a lamp.

The next component of the metaphor in question is that of niche (Mishkāt). This metaphor is the start of the parable of God's light. Ibn Manzūr defines this word in two ways: "the opening in the wall; not window" and "the iron that holds lamp." 24 The two definitions have a meeting point at the fact that they are the place within which lamp resides. Seyyed Hosein Nasr has a better

${ }^{24}$ Muḥammad Ibn Mukarram Ibn Manẓūr, Lisānal- 'Arab, Ṭab ‘a Gha dīda., 14, al-Mughallad al-Rābi‘ 'Ashar (Beirut: Dār Șādir, 1970), 441. 
description of the term as "a recess in a wall within which to set or hang a lamp." 25

When we try to collect discourse of the concept "Mishkāt" in the Quran, we would face a stumbling block of very little reference to it. Nowhere else this word is uttered by the Quran. ${ }^{26}$ In fact, its derivations have no place in the God's holy book. However, based on the only verse contains it, this word serves as the place wherein the source of everything benefit reside. The Arabs, for example, set a renowned Arabic maxim which says "philosophy issues from the niche of prophecy." 27

This parable of light, or metaphor in the widest sense of the term, has stimulates lively discussion among Muslim scholars, especially for those who are inclined to the philosophical and esoteric point of view until today. Niche is the container of the lamp which is the source of light. So, niche is not the light itself but it has the privilege to be the first object illuminated by light.

Inasmuch as that light is God's guidance, so niche is the first medium to which this guidance reaches. In the Islamic tradition, the heart of the believers is the "container" wherein the guidance of God illuminates. In this regard, it is understandable the notion that the real Quran - one type of lights - is what exist in the heart of the believers not only what is written down in paper. By this, we mean that the source of light we could generate from the Quran is what we understand it through our heart. Regarding to this understanding which reaches the heart, the Prophet Muhammad - peace be upon him - says about hypocrites' hearts (munāfiq) to which the Quranic teachings do not reach.

Applying this meaning to the light as God's guidance, it is only the heart of the believers, in the traditional meaning of the word, which could possibly accept this. As the material container, the "larger" the spiritual niche, the more rays of light it could

${ }^{25}$ Nasr et al., The Study.

26 Muḥammad Fu'ād. 'Abd al-Bāqī, Al-Mu'jam Al-Mufahras Li Alfāz AlQur'ān Al-Karīm: Bi Hāshīyat Al-Muṣhaf Al-Sharîf, 1. al-Ṭab'ah. (al-Qāhirah: Dār alḤa dīth, 1987), 387.

27 Seyyed Hossein. Nasr, Islamic Philosophy from Its Origin to the Present: Philosophy in the Land of Prophecy, sunny series in Islam (Albany: State University of New York Press, 2006), 3. 
accept. The "largest" and brightest light which this spiritual heart could contain is God. In this regard the famous prophetic tradition says of God's utterance, "My Heaven containeth Me not, nor My Earth, but the heart of My Faithful servant doth contain Me." ${ }^{28}$ It is clear, therefore, why in Islam "the heart" plays a vital role to which Sufis superiorly pay attention. That is why so many treatises exclusively dedicated to this aspect such as "Nourishment for Hearts", "Healing of Hearts", and "Light of the Heart".

Moving on the case that this light is the God's beautiful name, the heart of the believer could contain this light so that it manifests in his activity in the sensual world. A container of something by the course of time could be called by the thing it contains. For example, a bottle of perfume is referred as the perfume itself. For the same framework, the container of light manifests and is acknowledged as the Light itself. Of course, someone does not become God, but he or she illuminates God's beautiful attributes. Once one becomes really "near to" God and He love him, based on one sacred hadith (Qudsi), God becomes his hearing, his sight, his hand and his foot through which one acts in this corporeal world. By this, he completes the command of God as His vicegerent on earth (khalīfah Allāh fi al-arḍ).

By taking all our discussion into accounts, the metaphor of niche sets meaning as the heart of the believers. This heart is not a physical heart within our body, rather it is the heart with which one view the inner dimension of all being. It is the heart that always speaks to one's action whether his or her deeds are wrong or right.

\section{Unveil the Symbol of Lamp}

The lamp is in a glass

The next feature of the metaphor is the lamp. It is of important that the lamp here is the old oil lamp. Lexically the word "miṣbăh" is defined as the old lamp which needs oil to light

${ }^{28}$ Seyyed Hossein Nasr, "The Heart of the Faithful Is the Throne of the AllMerciful," in Paths to the Heart: Sufism and the Christian East, by James S. Cutsinger, The Perennial Philosophy Series (Bloomington: W orld W is dom, 2002), 32. 
up (sirāj)..$^{29}$ In the Quran, this word is mentioned 4 times. ${ }^{30}$ Two times in this verse while two others in plural forms in chapter 41 of Sura Fussilat ("Expounded") and chapter 67 of Sura al-Mulk, ("Sovereignty"). In those places, the term means lamp with emphasis point on the fact that itself has the source of light which is different from moonlight whose source of light is not from itself but from sun light. Therefore, stars are called lamps with which God has adorned the sky of this world which is called "the lowest heaven" by the Quran (Fușșilat [41]:12). By the lowest heaven, it includes the physical and spiritual cosmological doctrine in Islam. Human on the earth see only this lowest heaven above which many heavens exist. From this terrestrial heaven, one ascends to the celestial heaven in which the angelic realm lives.

The Quran also notes two important functions of these lamps. First, they act as adornments of the lowest sky. Second, they act as missiles against Satan. The latter symbolical language is better understood when the lamp as source of God's guidance is kept in mind. A believer who has this source of light in his/her heart, they have the missiles by which they shoot Satan in the form of human or jinn.

In the "Light Verse", this term plays an important role to allude the source of light in the heart of the believers. God has set His light on sacred scriptures, prophets, and Himself, but how people of believers catch this light? They need this "niche" in order to keep the light from being shut off or at least not focus. Therefore, the light will not bright because of the wind form the sides. In this allusion, the niche is understood as the sensual power with which human grasp the world and acknowledge God's messages in the first place. In the early life, with sight sense, human see God's creation; with hearing sense, human hear the sounds of this world; and with nose, human smell the world. This ability, however, often wrongly perceives the reality. Stars are seen so little before the eyes. Sun is no bigger than an orange. This "niche" after all is the capacity which is given to not only human

${ }^{29}$ Muḥammad Ibn Mukarram Ibn Manzūur, Lisān al- 'Arab, Ṭab'a Ghadīda., 2 al-Mughallad al-Thānī (Beirut: Dār Șādir, 1970), 503.

30 'Abd al-Bāqī, Al-Mu'jam, 399. 
but also animals. What they need in order to make this light brighter is the glass which makes the fire of the lamp focuses and keep the fire from wind.

\section{Unveil the Symbol of Glass}

The lamp is in a glass. The glass is as a shining star

We come to the next metaphor that is glass. Ibn Manzūr describes the word "zujājah" as "bottle" which is made of glass. ${ }^{31}$ This kind of glass is usually made for special light. Therefore, it is transparent glass chimney. In the Quran, the word "zujājah" is only found in this verse twice. ${ }^{32}$ When we consider the function of this glass chimney for the oil lamp, we could decipher the symbol it plays in this metaphor.

The glass performs a vital function as the protector of the fire from a blast of wind so that the fire becomes focus and brighter. The notion of making the potential light become stronger and focus could be resemblance with the intelligence power human have to perceive their world. Intelligence, 'aql in Arabic, keeps hum an from the error that their senses could not avoid. Sometimes your eyes see something as little as an orange, like sun, but your intelligence says that your sight is wrong. The sun, your intelligence proposes, is hundreds of thousands times bigger than what your sight suggested to you. ${ }^{33}$ When hum an could unlock his true potential of the intelligence, their glass is just like a shining star, which strengthens the light of the lamp.

However, this light could be not so bright if the oil with which the lamp is fueled is bad oil. The better the quality of the oil is, the brighter the light of the lamp would be. The next metaphor explains the next level of brightness.

${ }^{31}$ Ibn Manẓūr, Lisān al-'Arab, 287.

32 'Abd al-Bāqī, Al-Mu'jam, 330.

33 Abū Ḥāmid Muḥammad ibn Muḥammad al-Ghazālī and William Henry Temple Gairdner, The Mishkāt Al-Anwārof Al-Ghazālī (Forgotten Books, 1924), 89. 
Unveil the Symbol of Olive Tree

The glass is a s a shining star kindled from a blessed olive tree, neither of the East nor of the West.

"A blessed olive tree" translates "shajarah mubärakah." It is of important to elaborate the discourse of the word "zaytūn" and its derivation in the Quran. Before that, however, we need to consult with the Arabic dictionary to render the meaning of this word in classical Arabic. There are three words family which are addressed in the Quran, namely zaytun, zaytūn, and zaytūnah. Ibn Manzūur ${ }^{34}$ describes these three words into several meanings. The word zaytūnah is used as olive tree and its fruits. Meanwhile, the word zaytūn is the plural form of the latter word. The word zaytun is the extraction of this fruits from which the olive oil is derived.

In the Quran, the word zaytun is found once, zaytün 5 times, and zaytūnah is repeated once. ${ }^{35}$ In those places, the words do not only bear the meaning of empirical fruits or tree but also the intellectual meaning of the allusion of the Holy House which is placed in Jerusalem and the intellectual power which God has given to human. ${ }^{36}$ When we try to decipher the meaning of this metaphor here, olive oil is the source of the power of the light with which the lamp is kindled. The more natural the oil is, uncontaminated and pure, the brighter the light of the fire would be. We have set that the meaning of the glass is the intelligence power. In comparison to the place of the glass, physically speaking, the oil in the lamp is more hidden and deeply rooted below the glass chimney and the lamp. Thus, the access to this power, we could say, is so deep in the human soul. One would have access to it only when they could purify their soul. So that this power is the initiative of revelation that God gives to His prophets or it is of a direct intuitive knowledge, by which we mean as it is understood by traditional philosophy.

\footnotetext{
${ }^{34}$ Ibn Manẓūr, Lisān al- 'Arab, 35.

35 'Abd al-Bāqī, Al-Mu'jam, 334.

${ }^{36}$ Nasr et al., The Study.
} 
It is of important that the olive tree is neither of the East nor of the West. In Arabic, "east" refers to the rising of the sun, ${ }^{37}$ while "west" refers to the setting of the sun. ${ }^{38}$ In this regard, being not of the east nor of the west brings about the consciousness that the olive tree is in such on earth which makes it being poured by the sunlight all the time. ${ }^{39}$ Thus, such an olive tree produces the best extraction with which the light of the lamp becomes brighter, in this time, the brightest of its potentials.

This metaphor also means that the truth which is embodied in the light of the lamp arises from the center of the world not from the extremism. Being the center, the truth could act as a balancing power ("Axis Mundi") of the human souls between their animal and angelic tendencies, their profane life and the hereafter, their terrestrial and celestial realms. This notion of being center is vital in the Islamic faith. Truth in Islam should maintain the material and spiritual tendencies. Therefore, pure spirituality in Islam is beyond all oppositions. ${ }^{40}$

\section{Conclusion}

After being discussed in abovementioned sections, here, I would specifically analyze the benefit of Ricoeur's metaphorical concepts to the hermeneutic of the Quran. The Quran contains many metaphorical statements. In order to convey the meaning, Muslim commentators derive their explanations from the prophetic tradition and his companions' opinions. These two sources have been unchangeable since the early exegetical tradition. In the next phase, some Muslim scholars develop new approaches to explain metaphorical statements. For example, the explanations of the light of God as true light while for others is only metaphorical, as al-Ghazāilì explained, is totally new understanding of the verse. Here there are two benefits of adopting metaphorical concepts of Ricoeur.

${ }_{37}$ Muḥammad Ibn Mukarram Ibn Manẓūr, Lisān al- 'Arab, Ṭab'a al-a wwāl., 10, al-Mugallad al-‘'Āsirah (Beirut: Dār Șādir, 2000), 173.

${ }^{38}$ Ibid., 673.

39 Ismā'īl ibn 'Umar Ibn Kathīr, Tafsīr al-Qur'ān al- 'Azīm, ed. Muhammad Ḥusayn. Shams al-Dīn, al-Sādis. (Beirut: Dār al-Kutub al-'Ilmiyyah, 2006), 54.

${ }^{40}$ René Guénon, The Crisis of the Modern World (Sophia Perennis, 2001), 8. 
First, just as metaphor enrich and extent the idea in mind, Ricoeur's concept introduces new way of understanding metaphorical verses in the Quran that metaphor is about the discourse rather than only about the word. Before, the way to understand the metaphor in the Quran is always about the word not discourse. It serves a crucial function to pave way for new possibility to interpret the verses. For example, in the interpretation of the east and west in verse in question, the tradition always say that it is about the place wherein the olive tree being poured by sunlight all the time so the tree would produce the best extraction. By this new approach, we could extent the meaning to the axis mundi of which human could maintain their center which is so hard for modern human nowadays. Another example, the idea of God as Light proposes that the journey towards Him would sometimes "blinding" because of the direct light to which our eyes are heavily exposed.

Second, the idea of never-ending process between lexical meaning and metaphorical expressions bears in mind that the meaning of a "metaphor" always unveils some aspects but at the same time hides the others. By this, the dynamic process of interpretation could be maintained. The next generations always have the same opportunities to interpret the Qur'an, something that is scarcely left for Muslims in this modern era.

\section{Ascending Under the Divine Light}

The God's Light has been always a central issue in the Muslim scholars' discourses. Theological, legal, mystical and philosophical approaches have been employed to explain this "mysterious" metaphor. In this paper, we have discussed this metaphor under the concept of Ricoeur. Even though in some aspects this application and the interpretation of Muslims are resemblance, in the others Ricoeur's opens up fresh understanding of the verse.

God is always the center of attention to which Muslims' soul is always connected. He resides in the heart of people of believers according to the famous prophetic tradition. His light as we have discussed is the light above light. Hum an accepts this light based on how they employ five potentials God has given them and on the grace (barakah) they receive. In this paper, we have proved that 
the adoption of the new approach from different tradition is possible and in fact pave unique way to understand the verse.

\section{References}

Al-Halīil Ibn Ahmad, Ibn-'Amr, and 'Abd al-Ḥāmid Hindāwī. Kitā b al-'Ain. $4 \mathrm{~K}$ - y. Al-Ṭab'a 1. $4 \mathrm{~K}$ - y. Beirut: Dār al-Kutub al'Ilmyya, 2003.

Aristotle, and Samuel Henry Butcher. The Poetics of Aristotle. London: Macmillan, 1922. Accessed October 9, 2016. http://archive.org/details/poeticsofaristot00arisuoft.

Dirven, Rene. "Metaphor as a Basic Means for Extending the Lexicon." In The Ubiquity of Metaphor: Metaphor in Language and Thought, Amsterdam Studies in the Theory and History of Linguistic Science. Vol. 29. Amsterdam studies in the theory and history of linguistic science. Series 4, Current issues in linguistic theory, 0304-0763. Amsterdam [etc.]: Benjamins, 1985.

al-Ghazālī, Abū Ḥāmid Muḥammad ibn Muḥammad, and William

Henry Temple Gairdner. Ghazzali's Mishkāt Al-Anwār (The Niche for Lights). Lahore: Sh. Muhammad Ashraf, 1952.

- - - The Mishkāt Al-Anwār of Al-Ghazā̄ì. Forgotten Books, 1924. Guénon, René. The Crisis of the Modern World. Sophia Perennis, 2001.

'Abd al-Bāqī, Muhammad Fu'ād. Al-Mu'jam Al-Mufahras Li Alfāz Al-Qur'ān Al-Karìm: Bi Hāshīyat Al-Muṣhaf Al-Sharīf. 1. alȚab'ah. al-Qāhirah: Dār al-Ḥadīth, 1987.

Ibn Kathīr, Ismā'îl ibn 'Umar. Tafsīr al-Qur'ān al- 'Aż̄im. Edited by Muhammad Ḥusayn. Shams al-Dīn. al-Sādis. Beirut: Dār alKutub al-'Ilmiyyah, 2006.

Ibn Manẓūr, Muḥammad Ibn Mukarram. Lisān al-'Arab. Țab'a Ghadīda. 14, al-Mughallad al-Rābi‘ 'Ashar. Beirut: Dār Șādir, 1970.

- - - Lisān al-'Arab. Țab'a Ghadīda. 2 al-Mughallad al-Thān̄i. Beirut: Dār Șādir, 1970.

- - - Lis̄̄n al- 'Arab. Ṭab'a al-awwāl. 10, al-Mugallad al-'Āsirah.

Beirut: Dār Șādir, 2000. 
Jumhuriyyah Mișr al-'Arabiyyah. Mu'jam Alfāz Al-Qur'ān AlKarìm. Vol. 2. Majma' al-Lughoh al-'Arabiyyah, 1409.

Kort, W. A. "Book Review: Review Essay: Paul Ricoeur and the Hermeneutics of Metaphor, the Rule of Metaphor: Multidisciplinary Studies of the Creation of Meaning in Language." Christianity \& Literature 28, no. 2 (1979): 49-51.

Nasr, Seyyed Hossein. Islamic Philosophy from Its Origin to the Present: Philosophy in the Land of Prophecy. SUNY series in Islam. Albany: State University of New York Press, 2006.

Nasr, Seyyed Hossein. Man and Nature: The Spiritual Crisis of Modern Man. London (Ruskin House: Mandala Books, 1976.

- - - "The Heart of the Faithful Is the Throne of the AllMerciful." In Paths to the Heart: Sufism and the Christian East, by James S. Cutsinger. The Perennial Philosophy Series. Bloomington: World Wisdom, 2002.

Nasr, Seyyed Hossein, Caner Karacay Dagli, Maria Massi Dakake, Joseph E. B. Lumbard, and Mohammed Rustom. The Study Quran: A New Translation and Commentary. Tra edition. New York: HarperOne, 2015.

Ricoeur, Paul. Hermeneutics and the Human Sciences: Essays on Language, Action and Interpretation. Edited by John B. Thompson. Translated by John B. Thompson. New York: Cambridge University Press, 2016.

- - - Interpretation Theory: Discourse and the Surplus of Meaning . Fort Worth: Texas Christian University Press, 1976.

- - - The Rule of Metaphor: Multi-Disciplinary Studies of the Creation of Meaning in Language. Translated by Robert Czerny, Kathleen McLaughlin, and John Costello. London: Routledge \& Kegan Paul, 1978.

- - - "Toward Hermeneutic of the Idea of Revelation." Harvard Theological Review 70, no. 1-2 (1977): 1-37.

Shīrāzì, Shīrāzī Șadr al-Dīn Muhammad. Tafsīr al-Qur'ān Al-Karīm. Edited by Muhammad Khwajawi. Vol. 4. Qum: Intisharat-i Bidar, 1987. 